\title{
A PASSY PASSPORT
}

\author{
By Randolph G. Adams
}

Shortly before bis death the late Robert Hude Neilson, of the Class of 1903, gave to the Library, among a collection of rare materials, a passport printed by Benjamin Franklin at bis press at Passy. Counting on tbis piece of good fortune to bring us furtber luck, we asked Dr. Randolpb G. Adams, of the William L. Clements Library, to write an article on this precious yellowed sheet of paper. Dr. Adams graciously consented to write the following article, wbich becomes in a way an addendum to bis brocbure, The Passports Printed by Benjamin Franklin at his Passy Press, 1925.

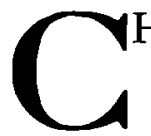

HARLES STORER may not have been the most important member of Benjamin Franklin's circle in France, but he knew how to get what he wanted. He first appears among Dr. Franklin's correspondents in a letter written in March of 1783 , in which he confesses an ignorance of Parisian manners and customs and asks the Doctor how he should behave. Could he have gone to any better fountain of wisdom in such matters? The record does not reveal what counsel the Doctor gave him, nor whether he took advantage of it. Perhaps 'tis just as well. Apparently Mr. Storer also desired to do a bit of travelling, and on April 8 of the same year, he secured a passport, duly signed by Benjamin Franklin, and countersigned by William Temple Franklin, which permitted "M. Storer, Citoyen des dits Etats" to go to Holland, with a servant. He may not have left at once, for certainly in June he was dining with the Doctor at Passy, but by August he was in England and by November he was back in France.

The passport used by Mr. Storer on his tour belongs to the Library at Rutgers University. It must be remembered that in the spring of 1783 , the War of the American Revolution had not yet been officially ended. Although Cornwallis' surrender at Yorktown was now eighteen months past, and although the preliminary Treaty of Peace had been signed six months before, Britain and the United States were still legally at war. American citizens needed passports with which to travel. Dr. Franklin as American envoy at Paris not only granted such pass- 
ports, - he printed them. It will be remembered that the Doctor wrote his own epitaph, in which he wished to be remembered as "Benjamin Franklin Printer."

Much has been written about Dr. Franklin's little "private press," which he operated at Passy during his tenure of office in France at the time of the American Revolution. Imprints of this Press have been "collector's items" for many years, and have fetched fancy prices whenever they came on the market. In I9I4, the Grolier Club published Luther S. Livingston's Franklin and bis Press at Passy, an ideal bibliography by an ideal bibliographer. This work described the thirty-two then known products of the Press at Passy. These ranged from the precious "bagatelles" which Doctor Franklin printed for the amusement of his lady friends, and others, to blank forms for official use in the conduct of his business. The Rutgers passport is Number $3^{\mathrm{I}}$ in Livingston.

Since I9I4, six additional imprints of the Passy Press have come to light. The first was identified by George Simpson Eddy of New York, and by him edited for reprinting by Bruce Rogers (who had also done the Livingston book) as $A$ project of universal and perpetual peace written by Pierre-André Gargaz ... and printed by Benjamin Franklin at Passy in the year 1782 (New York, 1922). Next, a variant of the passport was discovered by Dr. Worthington C. Ford, in the Vignaud collection at the William L. Clements Library, University of Michigan. This led to the discovery of two other variant printings of the passport, and the three were reproduced in The Passports printed by Benjamin Franklin at bis Passy Press (Ann Arbor, 1925). About the same time, Mr. Franklin Bache of Philadelphia, a descendant of Dr. Franklin, discovered some printed promissory notes in the Franklin papers which had come down in the Bache family. One of these was reproduced by Charles Bache and Louis C. Karpinski in an article in the Dearborn Independent for July, I925. Later, when the Bache collection was acquired by the American Philosophical Society, yet another imprint, An Ordinance [of the Continental Congress of 1782] was discovered by Mr. Bache. In 1926, the present writer found at the University of Pennsylvania Library a printed form of dinner invitation used by Doctor Franklin, 
and summed up the various additions to Livingston in an article in The American Collector, for August, 1927.

But to get back to the passports: Livingston described only one of the printing variants of the passports for persons (as distinguished from passports for ships). That is his Number $3 \mathrm{I}$, and it is identical with the Rutgers passport. However, as noted above, three other printing variants are now known and are described below. The text of all the passports is practically identical, it is only in typography that they differ materially. The text (which is in French, the language of diplomacy) was taken word for word from the current passports issued by the French government for use by its ambassadors. Of course, it would be difficult to decide exactly what particular document Franklin thus copied, but a shrewd guess may be made, because among the Franklin Papers at the Historical Society of Pennsylvania is such a French passport, signed in 1776 by de Noailles, the French ambassador at London, for the notorious Dr. Edward Bancroft. Franklin and Bancroft seem to have played hide-and-seek with one another's private and official papers, so perhaps the Doctor just "retained" this one. It may well have been the model for the Passy passports.

Following Livingston we have designated these passports as Livingston $3 \mathrm{I}, 3 \mathrm{Ia}, 3 \mathrm{Ib}$ and $3 \mathrm{IC}$. A census of surviving copies of the passports would run something as follows:

LIVINGSTON 3I: This is the Rutgers passport issued to "M. Storer." It is like that issued to "Mr. [Moses] Young" at the Massachusetts Historical Society, that issued to "Messrs. Rawle et M. Walker" at the Historical Society of Pennsylvania, and that issued to "M. Elkanah Watson," formerly the property of Watson Kent of New York and now owned by Dr. A. S. W. Rosenbach of Philadelphia.

LIVINGSTON 3Ia appears to have survived in three copies, two of which are in blank. One is in the library of the American Philosophical Society and the other in the William L. Clements Library at the University of Michigan. But the Clements Library also possesses another copy, made out to "Mr. Harmar, Colonel au Service des dits Etats." This is our favorite, because it was this very passport which Lieutenant Colonel (afterward General) Harmar used when he carried back to 
Paris the ratification of the Treaty of Peace between the United States and Great Britain, which ended the Revolution, in the making of which Treaty Doctor Franklin had had a large share. This copy was found among Harmar's papers, which are now at the Clements Library.

LIVINGSTON 3 Ib exists in apparently a unique copy in the William Smith Mason collection at the Yale University Library. It is made out to "Messrs. Jones et Paradise."

LIVINGSTON 3 IC is in blank and also exists in what is apparently a unique copy in the S. Weir Mitchell collection at the University of Pennsylvania Library.

The passports are rare, and any library is lucky to have one copy of one variant. When Doctor Franklin signed the Rutgers copy, and when, possibly, William Temple Franklin handed it to Storer, bibliographers were probably not aware of the importance their descendants would attach to these ephemera. Today, from the standpoint of the bibliographer, they are priceless. If more practical folk should enquire what the money value of any one of these single sheets of paper may be, the reply is always, "They are worth exactly what someone will give for them." Fortunately we have records on that, also. When the Watson Kent passport came on the auction market in the hilarious decade of the I920's, it fetched $\$ 1775$. If the curious wish to know what has occurred to that price since, he has only to examine Dr. Rosenbach's I94 I catalogue entitled "A bibliophile's miscellany," and he will see that whatever has happened to other forms of property, a Passy Passport is held at no less a price in the I940's than it fetched in the I920's. 


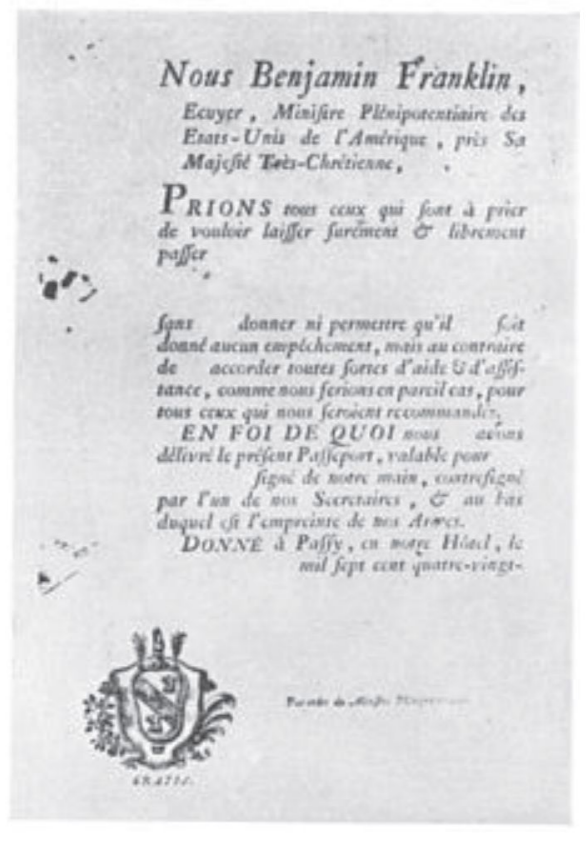

Livingston 3 IA

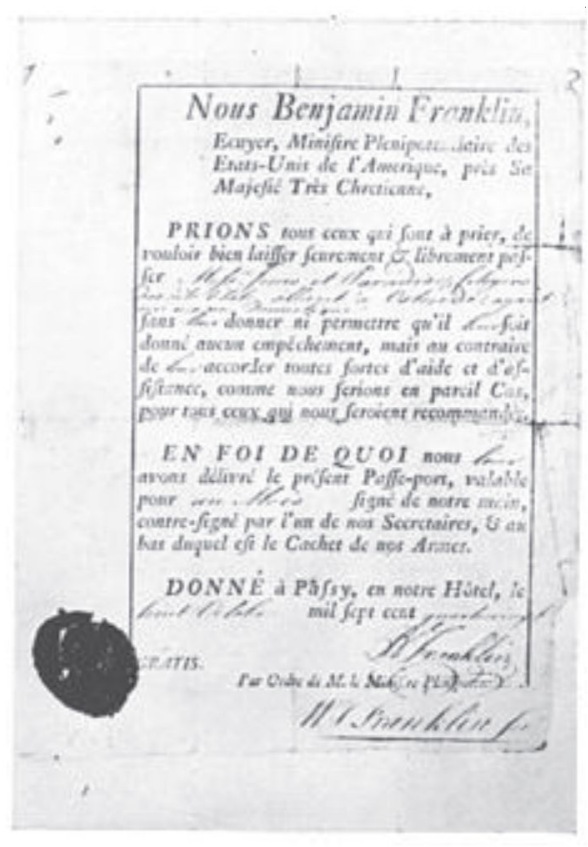

Livingston 31 B

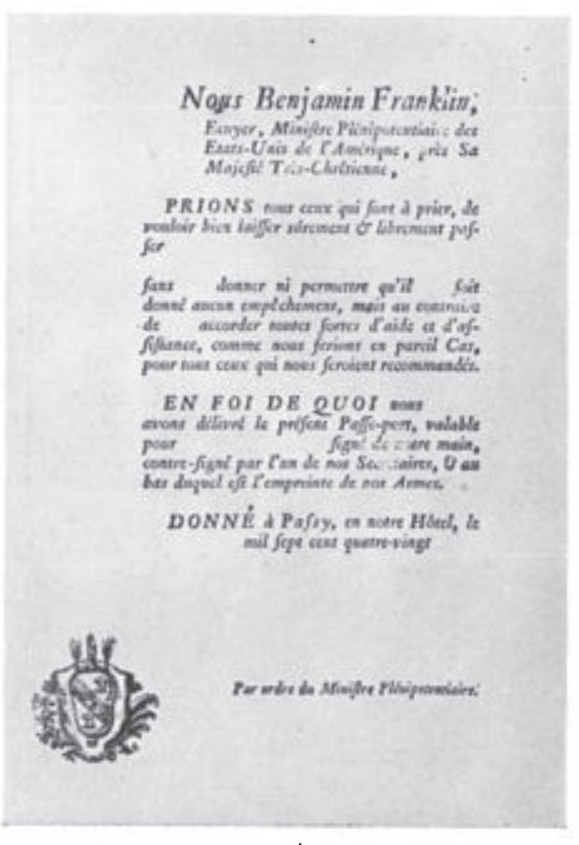

Livingston 3 IC 


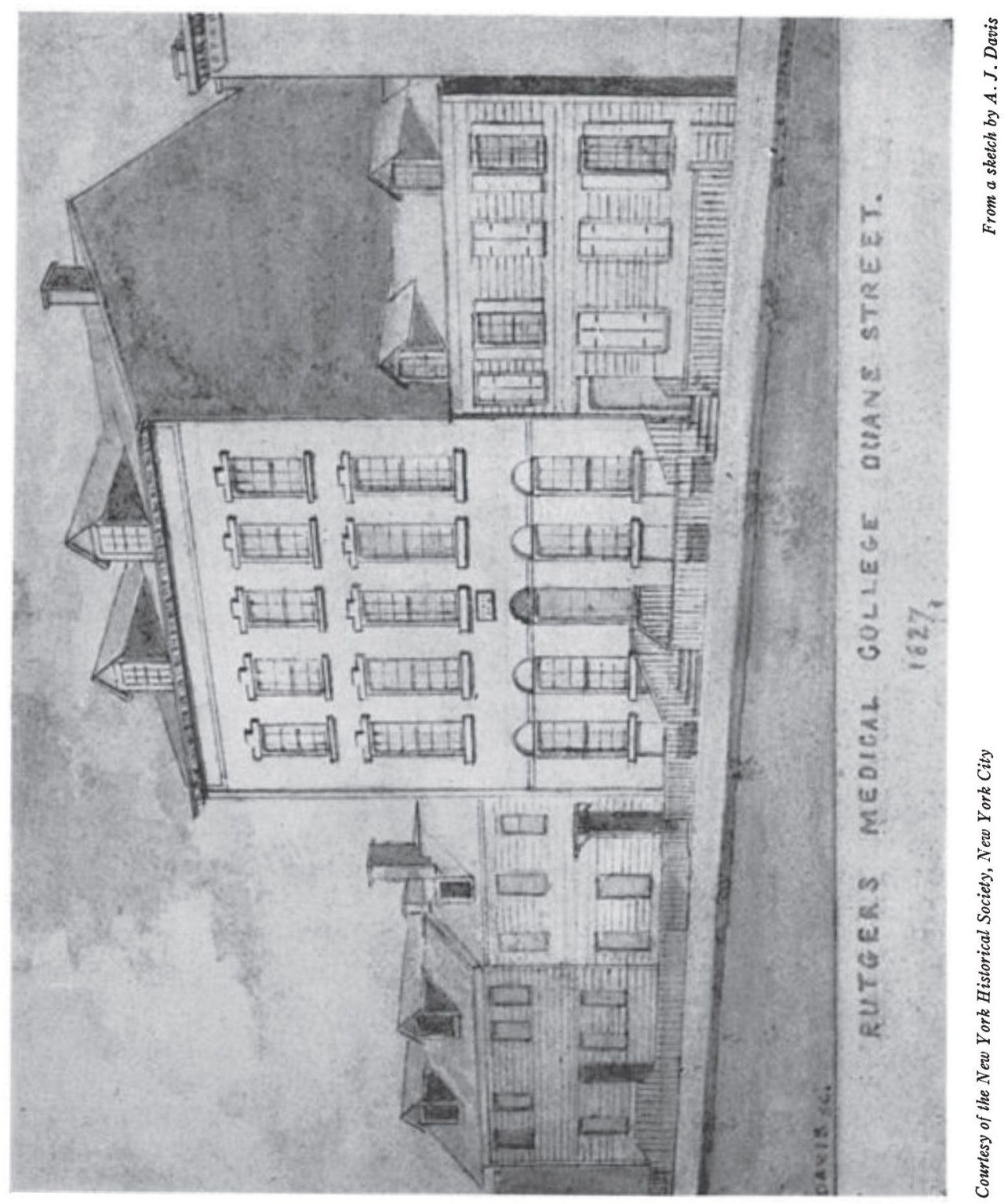

